\title{
Weed to achieve: a fundamental part of the public library mission?
}

\author{
Juris Dilevko*, Lisa Gottlieb \\ Faculty of Information Studies, University of Toronto, Toronto, Ontario, Canada M5S 3G6
}

\begin{abstract}
Weeding or deselection of materials has become an integral part of library management. Based on a nineteen-question survey about weeding practices in public libraries, this article discusses the personal perspectives of public librarians on weeding as well as the weeding practices of their institutions. The three most common criteria for weeding are circulation, physical condition, and accuracy of information. Librarians overwhelmingly believe that weeding increases use of books and patron satisfaction. In addition, the public library was framed as a venue that offers safe, clean, and fresh "product lines" with various natural life cycles and expiry dates. This discursive formation raises questions about the extent to which public libraries and their collections are becoming commodified, homogenized, and ephemeral, and whether such ephemeralness and homogenization serve the interests of all community members. (C) 2003 Elsevier Science Inc. All rights reserved.
\end{abstract}

Keywords: Weeding; Deselection; Collection management; Public libraries

\section{Introduction}

The question of whether a public library collection should be weeded has long been a controversial topic in the field of librarianship, generating lively arguments about the advantages or disadvantages of weeding. As Loriene Roy summarizes, the weeding debate can be traced back to Charles Francis Adams, Jr. and the Quincy Plan. Adams served as a library trustee for the Crane Memorial Public Library in Quincy, Massachusetts, which was built by Henry Hobson Richardson in 1882 [1]. Richardson's designs, Roy reports, were notorious for not taking into account future growth of the collection, and the Quincy library

\footnotetext{
* Corresponding author. Tel.: +416-978-7089; fax: +416-971-1399.

E-mail address: dilevko@fis.utoronto.ca (J. Dilevko).
} 
was no exception. By 1892 , there were 19,000 volumes in the collection, but the total projected capacity was only 20,000. Dire measures therefore had to be taken, and the so-called Quincy Plan - weeding all but the most popular materials, producing finding aids for readers, and transferring research materials to locations that were more convenient for potential users - was born. The plan caused great consternation, and heated discussion about it ensued at the 1893 American Library Association (ALA) convention. For example, William Poole, a founding member of the ALA, wrote that a concerted program of weeding would ensure that the library will have "no books which will interest persons with an intellectual range above that of clod-hoppers and market gardeners." Rather than weeding, libraries should adopt a policy of "adding the books which elevate the literary and historical taste of the public, in meeting ... the wants of scholarly readers, and not neglecting to provide the books for the young and the less educated class" [2]. Poole's comments about weeding were part of his campaign for better-designed and more capacious library buildings. In his mind, architects of libraries were overly concerned with aesthetic matters to the detriment of practical considerations such as sufficient space for books. He therefore wanted librarians to take the lead in developing new library buildings and floor plans, thus keeping a tight rein on the proclivity of architects for fanciful excesses [3]. If buildings were larger, weeding pressures would disappear or be mitigated.

In the $20^{\text {th }}$ century, the debate about weeding followed, for all intents and purposes, the contours of the controversy surrounding the Quincy Plan. On one side are those who believe that weeding is all about space: space must be made for current, useful materials that will actually circulate and make the library more appealing. On the opposing side are those who believe that other considerations beyond mere numbers must be taken into account when operating a public library. J. Wesley Miller, for instance, laments that librarians are "throwing away books with enough vigor to make book burnings under the Inquisition look like a hotdog roast at a Methodist Sunday-school picnic." Arguing that "antique books are not a renewable resource" and that "the enormous strength of the historic preservation and collectibles movement belie claims that there is no demand for worthwhile old books and authors," Miller suggests that "every public library should establish a substantial American Heritage collection containing the whole works of classic authors of Anglo-American culture up to 1900" and that, if any weeding is to be done, it must be left "to the most learned, experienced, and conservative of multidisciplinary information specialists" simply because "it takes a great deal of learning to know just how important minor authors are" [4]. Of course, a distinction should be made between the library's role with regard to retaining research materials and weeding of general collections. Central branches of systems often serve a research function, and thus the question of weeding in such research-oriented public units should likely be applied on a different basis than in non-research oriented units.

Another consistent feature of the weeding debate is that almost all of the literature about weeding is advocacy-based and prescriptive in nature, with a few controlled studies about whether weeding fulfils its goal of increasing circulation [5]. There is, for example, Joseph P. Segal's Evaluating and Weeding Collections in Medium and Small-Sized Public Libraries: The CREW Method, which provides a model for integrating weeding into the entire selection and acquisitions process. Segal suggests that books have "useful careers," but once these careers are over, they should be "retired" using a systematic approach that "streamlin[es] 
your collection for efficient and reliable use ... making it easier and faster for the people of your community to find the facts, phrases, and stories they need" [6]. His approach includes three components: the number of years since the book's latest copyright data; the number of years since its last recorded circulation; and the presence of various factors he labels as "musty" - misleading, ugly, superseded, trivial, irrelevant to a particular library's collection [7]. Stanley J. Slotes's Weeding Library Collections: Library Weeding Methods, published in a fourth edition in 1997, proposes that a variable called "shelf-time period," defined as the "time a book remains on the shelf between successive uses," is the best way to create "a smaller core collection that would satisfy a given level of predicted future use" [8]. Less formal approaches based on personal preferences are also prevalent. For instance, Cathy Carey advocates "survival weeding": "When going down an aisle in search of a history of Korea, pull those two tattered books on China. It takes only a second" [9]. Merle Jacob supplies "a handy rule of thumb for the types of books I weed" in the fiction collection, describing a process where she focuses on, among others, older single title authors, obscure foreign authors, earlier or lesser works of authors who have died, series books when titles are missing, and less important titles of classic authors [10].

Three examples of controlled studies about weeding in public libraries provided mixed results about the positive effect of weeding on circulation. Penelope McKee, after using the Slote method, observed that there was "a strong positive relationship between declining stock [due to weeding] and increasing circulation" [11]. Carolyn Moore found that, after weeding, the "use factor" of the photography section increased from $25 \%$ to $33 \%$, but that the "use factor" of the travel section remained at 9\% [12]. Loriene Roy, after four rural Illinois libraries were weeded of $10 \%$ of their circulating adult collection, noted that there was "no significant increase in stock turnover rate, total circulation, or adult circulation" [13].

Even rarer are surveys about how and why libraries — whether public or academic — weed. In the early 1970s Roscoe Rouse surveyed public and academic libraries about whether they practiced weeding, how many books they sent to storage, and how many books they discarded, but his main purpose was to determine the extent to which libraries use additional within-library space (e.g., various shelving techniques, storage areas, and annexes) to cope with weeded materials [14]. Elizabeth Futas and Jonathan Tyron, after surveying 60 public and academic libraries in Rhode Island, determined that more than $75 \%$ of the institutions had or were developing written policies (including retention schedules) for reference materials [15]. Carol Truett found that only two of her 14 surveyed libraries had written policies for weeding reference materials, although most of the libraries conducted systematic evaluations of their reference collections, paying special attention to age and use [16]. Perhaps the most wide-ranging survey was conducted by Eugene Engeldinger, who found that only 77 of 370 academic libraries $(20.8 \%)$ had a written policy about weeding reference materials [17]. Engeldinger also asked questions about the frequency of weeding reference materials, reasons for weeding, the number of volumes weeded annually, and the percentage of reference volumes transferred to the circulating stacks or discarded. 


\section{Purpose}

In light of the relatively few surveys about weeding practices in libraries, the purpose of this article is to determine current weeding practices of public libraries in North America with regard to their general (circulating) collections of fiction and non-fiction print materials through a set of survey questions touching upon both institutional and personal perspectives on weeding. The survey included the following issues: Is weeding considered as something that is an important part of library work? How frequently is it done? Why and how is it conducted? Are there any problems involved in weeding? What is done with weeded materials? What are the personal beliefs of librarians about weeding? Are there any improvements that can be brought to the weeding process? In what terms do librarians talk about weeding, and what do these terms suggest about the role of the library? In sum, this article presents an overview picture of weeding practices, beliefs, and issues in public libraries at the beginning of the $21^{\text {st }}$ century.

\section{Method}

In November 2000, graduate students enrolled in the course "Collection Development and Evaluation" at a library and information science program at a major North American university were given a class assignment in which they were asked to send a survey consisting of a set of 19 questions about weeding procedures to randomly-selected public libraries in the United States and the nine English-speaking provinces of Canada (see Table 1). There were 19 students in the class (see Appendix A for the names of participating students). Each student was assigned a page range from the American Library Directory $(A L D)$ and was then asked to randomly choose the names of about 40 public libraries from the assigned page ranges. All the pages in Volume I of the $A L D$ (covering the United States) were assigned as well as the appropriate pages covering Canada in Volume II.

In broad terms, the $A L D$ lists libraries by state or province. Within each state or province, libraries are listed in alphabetical order of the town or city name within that state or province. Public libraries are designated by the letter P. In general, the more libraries in a particular state, the larger the page range of library listings for that state or province in the ALD. Students were requested to devise a systematic random sampling technique for their assigned page ranges. Each student was instructed to count the total number of $\mathbf{P}$ designations in her/his assigned $A L D$ pages and then pick, after a random number start, every $x^{\text {th }}$ public library such that each listed public library had an equal probability of being selected. Students were also told not to select branch libraries.

Students then contacted their randomly selected public libraries by e-mail. An introductory e-mail was sent informing libraries about the nature of the survey and requesting their participation. The e-mail was addressed to the attention of the person who was in charge of collection development or the person responsible for weeding. In the case of small public libraries, the message was addressed to the Head Librarian. Librarians were offered a chance to decline to receive the survey by sending a return e-mail expressing their unwillingness to 
Table 1

Text of survey questions (all questions except \#1 refer to the general [circulating] book collection of public libraries [fiction and non-fiction] but do not refer to reference collections)

1. How many total print book volumes are currently in your public library?

2. What are the reasons that you weed the print material contained in your library's general book collection? Please list all the reasons why your library weeds.

3. Are there any factors that discourage the weeding of the print material in the general book collection of your library?

4. What are the criteria that you use to weed the print material in the general book collection of your library? Name all the criteria that you use, and indicate which criteria are the most important for your library.

5. How often do you weed the print material of the general book collection of your library? Is it on a regular basis, or irregular? If regular, what is the usual frequency of weeding? If irregular, when were the last two times that the general collection of your library was weeded?

6. What do you do with the weeded print material from the general book collection? For example, is it sold, discarded, does it go into storage, or do you do something else with it?

7. What are the position titles of the people who participate in the weeding process? For example, is it generally one person or a collective team effort? How does this process work? Give as much detail as possible.

8. Is there a chance for other members of the library staff or members of the community to review material that has been designated as "to be weeded" before it actually is finally weeded? How does this review process work? For example, is there one level of review or multiple review levels?

9. What is the position title of the person who has the final say on any weeded print book material?

10. Have you ever personally saved a book or books that should have been weeded, i.e., met your library's criteria for weeding? If so, why did you save this book or books?

11. Please give details regarding any complaints from members of the general public about weeded books.

12. Do you personally believe that weeding increases book usage? If yes, what is your reason for thinking this? If no, why not?

13. Do you personally believe that weeding increases the satisfaction of your patrons? If yes, what is your reason for thinking this? If no, why not?

14. Do you personally believe that weeding saves staff time? If yes, what is your reason for thinking this? If no, why not?

15. Do you personally think that weeding is necessary in order to make room for new technologies? If yes, what is your reason for thinking this? If no, why not?

16. Not taking into account the procedures that your library actually follows in weeding, what is your personal philosophy about weeding?

17. If you could personally make changes in your procedures for weeding books in your general collection, what aspects of your weeding procedure would you like to change and why?

18. In a perfect world, what would you personally do with the print material that your library designates for weeding?

19. Does your library follow any written guidelines for weeding the print material of the general book collection of your library? If so, what are these guidelines?

participate. If no expression of unwillingness was received within five working days, the actual survey was then sent to that public library.

All survey questions (except the first one) were open-ended. The survey itself was an e-mail message that contained the text of the 19 questions. In other words, survey respondents could answer the questions from within their own e-mail package without going to an external web site. Respondents could return their surveys simply by pressing the "reply" button on their e-mail packages. A total of 849 initial messages was sent out by the 19 students enrolled in the class. Twenty-six libraries declined to participate. Accordingly, 823 
surveys were sent to randomly chosen public libraries in the United States and the nine English-speaking provinces of Canada. Completed surveys were received from 294 libraries, for a response rate of $35.7 \%$. As a means of self-identification, respondents were asked how many print volumes their libraries possessed. Of the 294 reporting libraries, 287 provided this information. Libraries fell into the following categories: 52 libraries $(18.1 \%)$ had less than 20,000 print volumes; 64 (22.3\%) had between 20,000 and 49,999; $63(22 \%)$ had between 50,000 and 99,999; another 63 (22\%) had between 100,000 and 249,999; 28 (9.8\%) had between 250,000 and 499,999; $10(3.5 \%)$ had between 500,000 and 999,999; and seven libraries $(2.4 \%)$ had more than 1 million print volumes. In other words, $62.4 \%$ of responding libraries (179 out of 287) had fewer than 100,000 print volumes, and $84.3 \%$ of libraries (242 out of 287) had fewer than 250,000 print volumes. Answers were received from 38 states and eight Canadian provinces. The states and provinces not represented in the survey were: Alaska; Colorado; Connecticut; Delaware; Hawaii; North Dakota; Pennsylvania; Prince Edward Island; South Dakota; Tennessee; West Virginia; Wisconsin; and Wyoming.

Students submitted a written overview of their individual results for grading and class credit. That is, on average, each student received about 15 or 16 returned surveys, and wrote a brief 1,000 word essay about any trends that he/she was able to identify among his/her set of returned surveys. They were also asked to submit, in printed spreadsheet form, the complete texts of answers provided by their survey respondents to the 19 survey questions. For the purposes of the present study, answers from all 294 respondents were collocated and subsequently entered into electronic spreadsheet and word processing software programs. A content analysis of the responses for each of the 19 questions was then performed, and categories were developed to obtain the quantitative results presented below. In the presentation of results, quantitative results are supplemented and enriched by the verbatim comments of survey respondents. The text of the 19 questions used in this survey is provided in Table 1.

\section{Results}

\subsection{Frequency of weeding}

As shown in Table 2, a plurality of the surveyed libraries (33\%, or 97 libraries) weeded on an "irregular" basis as the need arose, while $23.8 \%$ (70 libraries) identified themselves as weeding on an ongoing continuous basis. If those libraries that indicated that they weed daily, weekly, or monthly are added to the "ongoing" category $(70+14+12)$, then $32.7 \%$ of surveyed libraries weed on an ongoing basis. Only a very small percentage of libraries weeded every three, four, or five years-14 libraries in total fell into these three categories (4.8\%).

Answers provided by many of the libraries indicated that weeding is often a herculean task. A common sentiment was that "[w]e are never done" weeding. For example, one librarian wrote that "we weed continuously. It takes us approximately 1.5 to 2 years to completely do the non-fiction collection. Then we start over again." Another noted that "staff are supposed to be weeding continuously ... and the extent of weeding is a factor in work performance evaluations and in branch visits by the coordinators of adult and youth services." Another respondent observed that "each reference librarian is assigned a range of Dewey 
Table 2

Frequency of weeding $(\mathrm{n}=294)$

\begin{tabular}{lc}
\hline Irregular (when needed) & $97(33 \%)$ \\
Ongoing (continuous) & $70(23.8 \%)$ \\
Yearly & $48(16.3 \%)$ \\
Every two years & $18(6.1 \%)$ \\
Monthly & $14(4.8 \%)$ \\
Weekly or daily & $12(4.1 \%)$ \\
Bi-annually & $8(2.7 \%)$ \\
Every three years & $7(2.4 \%)$ \\
Every five years & $4(1.4 \%)$ \\
Every four years & $3(1 \%)$ \\
Uncategorizable or no answer & $13(4.4 \%)$ \\
\hline
\end{tabular}

numbers that he/she is responsible for weeding and collection development on an ongoing basis." Still another explained that all "returned books are checked for condition and set aside for weeding on a daily basis." Finally, one library mentioned that the establishment of biannual Friends of Library book sales - one in the spring and the other in the fall - is a strong impetus for regular weeding.

Many libraries have adopted what could best be described as a mechanistic and quantitative approach to weeding. Consider the following example.

The more new materials we buy for a certain collection, the more shelf space we will need. We accession approximately 33,000 new items every year. If we use 10 books per foot as an average, that would mean we need 3,300 linear feet of available shelf space every year just for the new materials. That would average out to 157 bays of shelving (if you estimate 7 shelves of the standard 3 feet in each bay). If we didn't weed every year ... we [would] get into trouble fast.

To avoid getting into "trouble fast," many libraries rely on automated computer reports that identify low circulating items or items that have not circulated at all in the past $x$ years. These items are then reviewed and an assessment is made about whether they should be retained. Two libraries reported that they had quotas for weeding, whereby a certain percentage of the collection must be evaluated on an annual basis. Other librarians make periodic trips through the stacks on the lookout for overcrowded shelves or trust shelvers, pages, and patrons to alert them to overcrowded areas. Once spotted, these shelves then undergo rigorous weeding. One library has introduced annual shelf reading parties, where "a group of volunteers is introduced to basic shelf reading [principles] and our CREW deselecting method and we go through the whole collection." Another library system has set up a mailing list that alerts its staff on a regular basis about new editions and outdated materials. To say the least, weeding is taken seriously as an important component of library life.

\subsection{Reasons for weeding and criteria used}

The primary reason for weeding print collections was the need to ensure accuracy of information, followed by the physical condition of the item, space constraints, and low circulation (see Table 3). 
Table 3

Reasons for weeding*

\begin{tabular}{lr}
\hline Need to maintain accuracy of information & 240 \\
Physical condition of item & 208 \\
Space considerations & 188 \\
Low circulation of item & 169 \\
Duplicate copies exist & 76 \\
Need to keep the library as a current and vital resource & 74 \\
Age/copyright dates & 26 \\
Superseded editions & 25 \\
Gain more knowledge of library collection & 17 \\
Beyond collection scope of library & 8 \\
Availability of item in alternate format & 6 \\
Increases circulation and turnover rate & 5 \\
Unacceptable stereotypes or sexist terminology & 3 \\
\hline
\end{tabular}

* Multiple answers allowed.

Other reasons included duplicate copies, the availability of the item in an alternate format, and the desire to eliminate unacceptable stereotypes and sexist terminology. To a great extent, these are self-explanatory reasons. Less obvious, though inherently logical, reasons for weeding were also offered.

One such reason - touched upon by 74 respondents - is the desire to present the library as a vital, vibrant, and up-to-date community resource. In the words of one survey participant, weeding "gets rid of that stereotype that the library is a dusty archives." Another commented that weeding "enhances the library's reputation" for currency and overall significance in the community. A third respondent noted that "our mandate, as a medium sized public library, is not to be that of an archive-we can only stock items of continuing and current interest to our patrons."

In addition, 17 respondents indicated that weeding increases knowledge of the collection as a whole. Weeding, one librarian wrote, is the "best way to go book by book and be reminded of what is in my collection. I get to see first hand [not only] what materials are damaged, need updating, or need to be replaced [but] I can also see what people are reading the most and where their real interests are." Another librarian explained that weeding helps "to become familiar with authors and their works." It also allows librarians "to gather information on collection strengths and weaknesses." Finally, it functions as "an integral part [of library work] in meeting assessed community needs." Weeding, in other words, not only discards items, but also awakens librarians to the hidden and forgotten resources that their shelves contain. In sum, systematic weeding is considered by many to be "a public service" that is the very antithesis of "irresponsible disposal of public property" because it often increases use and leads to a more attractive collection.

While librarians cited the need to ensure accuracy of information as the single most important reason they weed, circulation data were mentioned as the main criterion used to decide whether an item should be weeded (see Table 4). To be sure, many librarians wrote that "there is no most important factor" insofar as such considerations as timeliness of information, circulation statistics, and condition and attractiveness of the book should all play a role in making a weeding decision. Indeed, the CREW and WIDUS methods- 
Table 4

Formal criteria used to make weeding decisions

\begin{tabular}{llc}
\hline & $\begin{array}{c}\text { Cumulative } \\
\text { Mentions* }\end{array}$ & $\begin{array}{c}\text { Criterion } \\
\text { mentioned first }\end{array}$ \\
\hline Circulation of item & 196 & 74 \\
Physical condition of item & 176 & 45 \\
Accuracy of information contained in item & 154 & 75 \\
Age of item & 47 & 21 \\
Item is sexist, racist, or politically inappropriate & 43 & 22 \\
Existence of duplicates & 34 & 7 \\
Space considerations & 25 & 14 \\
Recommendations from subject bibliographies or other weeding lists & 24 & 4 \\
CREW method (Continuous Review, Evaluation, and Weeding) & 23 & 22 \\
Superseded editions & 17 & 1 \\
Local relevance & 13 & 3 \\
Library mission & 7 & 4 \\
Presence or absence of other books on the same topic & 5 & 1 \\
Constituent part of ongoing series & 3 & 0 \\
WIDUS method (Worn out, Inappropriate, Duplicated, & 2 & 1 \\
Uncirculated, Superseded) & & \\
Out of print & 2 & 0 \\
Available through inter-library loan & 1 & 0 \\
\hline
\end{tabular}

* Number of times a given criterion was mentioned in a respondent's top three criteria for weeding.

specifically mentioned by 23 and two respondents, respectively-are based on multiple criteria.

Nevertheless, librarians most often circled back to the central importance of circulation counts in weeding decisions. One respondent was enthusiastic about how he/she uses circulation statistics:

Because we have an automated system we can crank out weed lists on different criteria ... and we do. Because utilization of the same criteria time after time would not result in a 'refreshed' weed list, each list will be different. Our major criterion is patron usage. Non-use is the kiss of death. Our criteria will usually have one factor [connected with] use-e.g., under 10 checkouts and published before 1990. Another might be less than 10 checkouts in the last 4 years and owned by the mother area library. Each list is different.

According to another librarian, weeding should not be considered an isolated activity, but one that is performed as a natural part of the book selection cycle. As one examines circulation statistics about low-circulating titles, it is necessary to "consider whether it is the only book on that particular subject that we have ... [whether] it could or should be reordered, and whether or not there is another similar work which we should consider ordering as a replacement. It makes sense to research and record necessary buying information while weeding in order to preclude future gaps in the integrity of the collection." Thus, it is a good idea to keep "online book stores just a click away on your computer screen for quick checks as you check circulation statistics." Clearly, weeding is not seen as a negative that decreases the quantity and quality of a collection, but as a positive element that ensures a dynamic, responsive, and living collection. As the above examples demonstrate, 
Table 5

Factors discouraging weeding*

\begin{tabular}{lr}
\hline Time & 107 \\
Hesitancy in weeding local history materials & 53 \\
Hesitancy in weeding "classics" & 41 \\
Reluctance due to fear that item might be needed in the future & 37 \\
No factors discourage weeding & 35 \\
No money to replace weeded books & 34 \\
Hesitancy in weeding out-of-print books & 25 \\
Hesitancy in weeding one-of-a-kind books (i.e., only book on a particular subject) & 19 \\
Vocal public opposition by members of general public and elected officials & 18 \\
Hesitancy in weeding "hard to replace" materials & 16 \\
Hesitancy in weeding "high-demand" items even if such items are in poor condition & 15 \\
Hesitancy in weeding donated/memorial items & 10 \\
Lack of staff & 6 \\
No storage space available for weeded materials & 6 \\
Inclusion in standardized lists such as Public Library Catalog & 5 \\
State standards require $x$ amount of books per population served or funding formula & 3 \\
$\quad$ increases based on number of books per capita &
\end{tabular}

* Multiple answers allowed.

many librarians firmly believe that innovative use of circulation data aids in this replenishment process.

\subsection{Factors discouraging weeding}

If librarians recognize that there are many virtues to weeding, a number of factors nonetheless coalesce to inhibit weeding. Of these, lack of time is the most prevalent factor (see Table 5). The constant press of other duties, coupled with the fact that weeding is a time-intensive activity, caused many librarians to complain that there never seems to be enough time to engage in as thorough a weeding as they would like. Librarian hesitancy to weed individual titles or types of titles also was cited as an important factor discouraging weeding. Such hesitancy centered around local history materials, books by local authors, classics, out-of-print books, donated books, and items that an individual librarian had a hand in purchasing. Few librarians (only 34) mentioned that they were concerned about the lack of money to replace weeded books. Fewer still (only 18) noted that it was unpleasant to receive public complaints about weeded material. Perhaps the most intriguing responses came from three respondents who stated that they are reluctant to weed either because of state standards mandating a certain number of books per capita of population served or because of state funding formulae that tied an increase in collection development budgets to book titles held per capita.

In general, librarians commented that "the smaller the town, the more heat the Library takes about weeding" because people get attached to their books and fear that "they won't get other books to take the place of the old ones." Yet public complaints may quickly turn into public praise once the initial reluctance to weed disappears. In this regard, one librarian stated that he/she weeded 15,000 books during a one-year period, and "the response from the 
public (heard frequently) was: Oh, it is so much easier to find things now." In broad terms, lack of weeding was associated with fear, inertia, and a "packrat mentality," causing one librarian to remark that it is "time to weed librarians who don't want to weed." From a philosophical perspective, weeding seems to be an issue that separates librarians who wish to preserve books that might one day be needed from librarians who are committed to a more streamlined and proactively managerial approach to library operations.

\subsection{The process of weeding and its aftermath}

Do public libraries follow written guidelines of some sort when weeding? Of the 281 respondents to this question (see Question 19 in Table 1), $210(74.7 \%)$ indicated that their library did in fact rely on written guidelines. Of these, $45(21.4 \%)$ respondents specifically mentioned the CREW method. A wide range of other guidelines were also used, including a library's own collection development policy, ALA weeding rules, policies set forth by state agencies or departments, and the Sourcebook for Small Libraries.

Most libraries employ a team concept when weeding. Of the 292 replies received to Question 7 in Table 1, 251 respondents (86\%) indicated that at least two people participate in the formal weeding process. Of the 41 respondents who said that weeding at their libraries was a solo effort, most were from libraries where they themselves were the only person on staff. The team may consist solely of professional librarians, or it may include professionals, paraprofessionals, and occasionally volunteers. A common approach is to divide the collection into sections, with each person being assigned a section that is then double-checked by another person. Typically, if paraprofessionals have done the initial weeding, then one or two professional staff members review their selections before any items are officially discarded. As a further check, the person in charge of collection development for a particular subject area may also review the weeding choices. Is there room for review of material that has been designated as needing weeding? Of the 290 respondents to this question (see Table 1, question 8), 149 (51.4\%) indicated that library staff reviewed items after they had been initially selected for weeding; 123 libraries (42.4\%) had no review procedures; 15 libraries $(5.2 \%)$ allowed members of the public to review weeded materials; and three libraries (1\%) had review processes involving the Library Board and trustees.

In many libraries, weeding often resembles a military operation. Assistants "pull" the items or tag them with "weeding action slips." The items are then reviewed by the assistant's immediate supervisor, who then sends them to catalogers so that the items may be deleted from the library catalog or noted as being held in storage. Catalogers may flag an item as being worthy of retention, and then that item is returned to appropriate departmental supervisors. But who has the ultimate say about whether an item should be weeded? Out of 259 clearly interpretable responses, 174 respondents $(67.2 \%)$ indicated that the final decision was taken at the very highest level of the library hierarchy by a person with the title of Director, Chief Executive Officer, Chief Librarian, or Head Librarian. Conversely, 85 respondents $(32.8 \%)$ indicated that the final decision remained at the level of a department head: Adult Services Librarian; Collection Development Manager; Assistant Director; Reference Librarian; Branch Manager; Head of Reference; and Head of Technical Services. 
Table 6

Public reaction to weeding decisions $(\mathrm{n}=282)$

\begin{tabular}{lc}
\hline No complaints & $158(56 \%)$ \\
Complained that particular items were missing & $34(12.1 \%)$ \\
Complained about books being found in the dumpster & $21(7.4 \%)$ \\
Complained about library not keeping everything & $17(6 \%)$ \\
Complained that weeded books were a waste of taxpayers' money & $15(5.3 \%)$ \\
Complained that they did not understand the concept of weeding & $12(4.3 \%)$ \\
Complained about the library getting rid of "perfectly good books" & $10(3.5 \%)$ \\
Complained that donated material was weeded & $5(1.8 \%)$ \\
Complained about throwing out "classics" & $4(1.4 \%)$ \\
Complained that there was too little weeding & $4(1.4 \%)$ \\
Complained about empty shelves after weeding & $2(0.7 \%)$ \\
\hline
\end{tabular}

Judging by the titles of the individuals involved in final decision-making, weeding is considered to be a vitally important aspect of library work.

In light of the importance that professional librarians place on weeding and the large amount of staff resources and time libraries expend on it, what is the reaction of the public? As shown in Table 6, 56\% of librarians stated that members of the public had no complaints about weeding and another $1.4 \%$ of respondents indicated that patrons complained that there was too little weeding. Conversely, $42.6 \%$ of librarians listed a wide variety of negative complaints from the public about the weeding process, ranging from particular items, especially classics, being missing from the shelves, to anger at finding hundreds of books discarded in local dumpsters, to outrage that taxpayers' money is being wasted when items are weeded. In the face of these public complaints, librarians in turn complained that the public did not understand the library's mission-"we are a circulating library not an archive" - and about "local officials [who] haven't a clue as to what keeps a public library dynamic." One librarian believed that opposition to weeding was a generational issue insofar as most of the complaints emanate from people who lived through the Great Depression in the 1920s and were thus brought up to be frugal and not throw anything away. In order to better educate the public, some libraries have taken out advertisements in local newspapers about the reasons for weeding and have formed committees to define in precise terms what will and will not be kept. For example, one librarian explained that her/his library has a policy, developed by a committee, whereby all books mentioned in the semi-annual New York Times "Notable books" list are kept regardless of demand for 10 years. Although methods such as these may help in reducing public complaints about weeding, $42.6 \%$ of public library patrons nevertheless expressed some level of dissatisfaction with weeding. Such complaints may reflect weeding policies that are not taking into consideration the needs of public library users for materials that are not exclusively current and new.

\subsection{Fate of weeded materials}

Weeded material most often ended up being sold, either through formal Friends of the Library (FOL) books sales, informal and ongoing in-house sales, or to book dealers and eBay auctions (see Table 7). Sending weeded books to be trashed or to paper recycling centers 
Table 7

Fate of weeded items*

\begin{tabular}{lr}
\hline Friends of the Library (FOL) book sales & 154 \\
Trashed & 124 \\
Ongoing in-house sales (not FOL) & 116 \\
Donated & 72 \\
Recycled & 52 \\
Given to other libraries & 32 \\
Storage & 31 \\
Offered free to the public & 6 \\
Send to exchange book programs & 4 \\
Sell to book dealers and eBay auction marketplace & 4
\end{tabular}

* Number of times a given answer was mentioned in a respondent's top three answers.

were two other common options. Trashing books, however, was recognized to be a perilous undertaking, something to be done "quietly," "under the cover of darkness," and "in a locked dumpster" because discarded materials have occasionally been "returned by dumpster rats who cannot bear to see books thrown away." On the other hand, many libraries donated their books to a variety of public and social organizations, thus extending the use value of the weeded item in question. Nursing homes, retirement centers, Veteran's centers, women's shelters, Head Start programs, prisons, and psychiatric hospitals were often the beneficiaries of weeded books, especially large print editions. In addition, new library branches received weeded material to boost their initial stock. Another librarian noted that a "small college nearby takes many [of our books] to build up [its] library and get accreditation." One library stores its weeded material and waits "for delivery of a shipment container to send surplus weeded books to needy nations." Other libraries have formal arrangements with charitable organizations that pick up weeded material and distribute it to third world countries in Africa, Asia, and South America. Another library offers "our older, but still in good condition material, to smaller city, township, or village libraries in our County." Still another library has made arrangements with nearby Native American tribal nations to donate its weeded materials.

As altruistic as these solutions are, they are comparatively rare, especially in relation to the number of libraries who sell weeded books. No doubt many libraries rely on the extra income that such sales bring in-income that typically results in the purchase of new items for the library. Libraries are therefore caught in a conundrum. While the income generated from book sales contributes to a library's financial health, such sales may not have quite the same moral force as donations to social organizations or other solutions. Would librarians therefore personally like to see changes in the way their libraries dispose of weeded materials? As Table 8 shows, if all the responses where the word "sell" appears first are summed, then 115 librarians ( $40.9 \%$ of 281 total responses) believe that selling is the "perfect world" solution to dealing with weeded materials. On the other hand, if all the responses where the word "donate" appears first are summed and then added with the category "find each item a new home," then only 65 librarians (23.1\% of 281 total responses) believe that donations are the "perfect world" solution to the disposal of weeded materials. Perhaps not surprisingly, the personal views of librarians parallel what is actually being done with weeded books by their 
Table 8

Fate of weeded items "in a perfect world" $(\mathrm{n}=281)$

\begin{tabular}{lc}
\hline Sell the weeded items & $82(29.2 \%)$ \\
Find each item a new home & $31(11 \%)$ \\
Recycle & $29(10.3 \%)$ \\
Donate the items & $28(10 \%)$ \\
Discard & $25(8.9 \%)$ \\
Keep more items & $16(5.7 \%)$ \\
Sell, then donate the rest & $14(5 \%)$ \\
Give to other libraries & $11(3.9 \%)$ \\
Sell, then recycle the rest & $11(3.9 \%)$ \\
Give items away free & $6(2.1 \%)$ \\
Sell, then throw away the rest & $6(2.1 \%)$ \\
Donate, then recycle the rest & $6(2.1 \%)$ \\
Make the books disappear & $5(1.8 \%)$ \\
Book storage facility & $5(1.8 \%)$ \\
Take the books home & $3(1.1 \%)$ \\
Sell by having a year-round Friends of Library store & $2(0.7 \%)$ \\
Digitize weeded items & $1(0.4 \%)$ \\
\hline
\end{tabular}

libraries. Indeed, one reason for the reluctance of librarians to donate weeded materials to less-advantaged groups may be that such donations raise the thorny question of intrinsic worth. One librarian bluntly wondered about the ethics of sending "crummy looking books with information that is incorrect or obsolete to the needy [because] everyone should have access to good material." Another equated donating weeded materials with "sending worn out clothes to goodwill. If it isn't good enough for this library, it probably isn't good enough for another library! ... I personally hate seeing our outdated material with inaccurate information being bought up by families doing home schooling." Although donations may salve the conscious of some, for others donations imply a two-tier model of information access - another manifestation of the information divide where marginalized and less fortunate groups of people must make do with the discarded materials from privileged societal groups.

Nevertheless, there were a number of noteworthy suggestions that went beyond the "sell, trash, and donate" nexus. Five librarians recommended the establishment of a centralized storage facility to which all libraries could send their discarded materials. This storage center, functioning in the words of one respondent as "a clearinghouse or network to identify libraries or organizations that need books," would serve as a transshipment facility. Various charitable or social organizations could then come to this centralized depot and pick out what they needed. Alternatively, this central depot could be accessible to other libraries in "an amazon.com style way." This recommendation fits nicely with the plea of another librarian for a much-needed "last copy center" that would link all libraries within a geographical region in a powerful inter-library loan consortium. Indeed, the establishment of regional "last copy centers" may be a boon to public libraries insofar as it may free them to weed their local collections, secure in the knowledge that their local weeding decisions are not, in fact, getting rid of hard-to-find or impossible-to-find titles. 
Table 9

Personal beliefs about weeding $(\mathrm{n}=294)$

\begin{tabular}{llllc}
\hline Question & Yes (\%) & No (\%) & $\begin{array}{l}\text { Don't know or } \\
\text { maybe (\%) }\end{array}$ & $\begin{array}{l}\text { No response } \\
(\%)\end{array}$ \\
\hline $\begin{array}{l}\text { Have you ever personally saved a book } \\
\text { or books that should have been } \\
\text { weeded, i.e., met your library's criteria } \\
\text { for weeding? }\end{array}$ & $211(71.8 \%)$ & $75(25.5 \%)$ & $0(0 \%)$ & $8(2.7 \%)$ \\
$\begin{array}{l}\text { Do you personally believe that weeding } \\
\text { increases book usage? }\end{array}$ & $270(91.8 \%)$ & $8(2.7 \%)$ & $10(3.4 \%)$ & $6(2 \%)$ \\
$\begin{array}{l}\text { Do you personally believe that weeding } \\
\text { increases the satisfaction of your } \\
\text { patrons? }\end{array}$ & $253(86.1 \%)$ & $16(5.4 \%)$ & $15(5.1 \%)$ & $10(3.4 \%)$ \\
$\begin{array}{l}\text { Question } \\
\begin{array}{l}\text { Do you personally believe that weeding } \\
\text { saves staff time? }\end{array}\end{array}$ & $158(53.7 \%)$ & $82(27.9 \%)$ & $44(15 \%)$ & $10(3.4 \%)$ \\
$\begin{array}{l}\text { Do you personally think that weeding is } \\
\text { necessary in order to make room for } \\
\text { new technologies? }\end{array}$ & $135(45.9 \%)$ & $117(39.8 \%)$ & $35(11.9 \%)$ & $7(2.4 \%)$ \\
\end{tabular}

\subsection{Effect of weeding on library staff}

As discussed in previous sections, weeding demands a considerable deployment of human resources. Is this investment of human resources a sound one? Does the time devoted to weeding detract from other pressing tasks that staff might be doing, or is it a productive long-term investment that pays off in unintended ways? Opinion was mixed about whether weeding saves time. While $53.7 \%$ were of the opinion that weeding did save time, $27.9 \%$ held the opposite view and another $15 \%$ could see both sides of the question (see Table 9, fourth question). To be sure, the physical act of weeding took up a considerable amount of valuable time, and so many librarians were literally incredulous that weeding could be considered, in any shape or form, as a timesaver. Others begged to differ. Weeding, many felt, increased staff awareness of the collection, which was a boon for collection development practices. For instance, one librarian explained that "regularly working the shelves for the purpose of weeding helps staff get to know their collections. I get better collection priorities feedback from staff who are weeding advocates than I do from staff who are weeding aversive. In fact, weeding aversive staff tend to spend a lot more time complaining about having nothing on the shelves - instead of helping build those collections for customer use." Ten respondents noted that weeding is a great timesaver for reference staff, because "every book is potentially a reference book [and] weeding cuts down on the number of sources that contain out-of-date information." Reference staff therefore do not have to waste precious time looking in sources that might turn out to be erroneous, or in wading through only marginally useful sources that have not been weeded. In addition, weeding helps to provide better reader's advisory services: since shelves are in better order and contain more space, returned books can be shelved more accurately, which facilitates finding just the right title for patrons. Two notions of time are evident in these answers. Weeding may be a time burden 
Table 10

Changes needed to improve weeding procedures*

\begin{tabular}{lr}
\hline No changes needed & 157
\end{tabular}

More time needs to be set aside for regular weeding $r$

$\begin{array}{lr}\text { More staff needed to help weed } & 25\end{array}$

More training needed to better understand the concept of weeding $\quad 17$

More storage space and storage shelves in library needed 11

Book depot needed external to the library 6

More weeding needed

Less weeding needed

Automation needed

Bigger budget for weeding

Community experts needed

Weeding procedures must constantly evolve

Weeding teams needed

Handheld scanners for efficiency

Written policies needed

Weeding teams needed

More review [of procedures] needed

* Multiple answers allowed.

in the short term, but in the long run, many libraries feel that much time is saved in collection development and reference functions.

\subsection{Recommendations for improving the weeding process}

In general, survey respondents were quite pleased with weeding procedures at their public libraries. As shown in Table 10, 157 respondents stated that they personally would not implement any changes to their library's weeding procedures. Despite such a high level of satisfaction, a number of librarians felt that more time, money, and staff should be allotted to weeding. To streamline the weeding process, a small number of respondents also expressed a wish for more storage space, book depots, and handheld scanners. In addition, 17 respondents wanted to implement better training practices so as to make staff better understand the concepts behind weeding and the need for continuous evaluation and review of materials. Representative of this group of librarians was the following comment: "The only change I would make is to increase the training and commitment of the library staff evaluating their collections - the human element and personal distaste for weeding makes or breaks weeding." If staff are content to wait until "weeding is a major trauma," everything "falls apart." Another librarian mentioned that workshops about weeding should be offered to the public because, in her/his experience, once weeding concepts and principles have been explained to patrons upset about not finding their favorite books, they "were okay" with it. Perhaps the most original suggestion was offered by the librarian who wanted more community involvement in weeding. This respondent would use "experts in their field," who would be assigned to relevant sections of the collection, as well as "young people to do the bibliographic checking [because] I think it is a great way to learn about the world of letters." Some of these ideas could be combined. If time and staff resources are at a premium and if 
weeding is a time-intensive and labor-intensive process, then reaching out to involve community members in weeding may be a useful solution.

\section{Discussion}

\subsection{Socio-cultural implications of weeding}

To say the least, public librarians are firmly committed to weeding and its perceived benefits. As shown in Table 9 (first question), a large majority of respondents (71.8\%) have never personally saved a book that should have been weeded (i.e., met the library's criteria for weeding). Still, $25.5 \%$ of librarians had done so for various reasons, and their comments provide a glimpse into some of the socio-cultural implications of weeding. Local history titles were often saved, as were donated items, award winners, classics, and last copies in a consortium catalog. Occasionally, librarians even ventured to save "good" books that have not circulated within a given time period because such books "add depth to the collection" and "you want to give them one more chance." Another librarian averred that he/she had saved titles from weeding "because I liked them or because I thought a public library should own them even if they didn't circulate." Beyond such sentimental reasons, four librarians admitted that they saved potential weeding candidates in order to give them one last chance to be "discovered." It is a matter of willpower, one librarian wrote, because "with a little push, I [know that I] can find a readership for the item! Maybe a display on the subject?"

Other respondents weighed the historical and socio-cultural value of titles before permanently discarding them. One librarian was especially concerned about books that were examples of the evolution of socio-cultural phenomenon, saving titles where the "format shows how books have changed over the years (beautiful engraved covers, black and white children illustrations, etc.)." Another librarian paid special attention to first editions, citing "an original edition of a book written by William Jennings Bryant about evolution and the Bible from the time of the Scopes trial." Still another respondent rescued the work of a Nobel Prize winner: "a staff member tried to weed Samuelson's Economics last week. I brought this to the staff meeting and showed staff that Samuelson won a Nobel Prize for economics and that this is considered a classical work and ought to be kept." Another librarian "reversed a decision on an Encyclopedia of Art that was old and needed rebinding. The original employee felt that the Grove Dictionary was a sufficient substitute. When it was pointed out that the first title was a classic set and had color plates (which Grove doesn't), the item was sent to the bindery and will be placed back on the shelf when it returns." Personal and detailed knowledge of the collection, this librarian concluded, was indispensable to sound decision making in all weeding decisions. Another librarian eschewed hard statistical data, instead basing his/her decisions on an intimate knowledge about the community served and the tastes of individual readers: "at times one might retain a book or an author because one knows that there are members of the community who still read a particular author or type of book." Finally, another librarian took into account whether a particular title could, in some way, be needed "to answer future central library reference questions [insofar as] the other libraries in the county send us their most difficult reference questions." 
Perhaps the most intriguing comments came from three librarians who were not convinced that circulation statistics were reliable indicators about which books to weed. One of these respondents wrote that "sometimes books that end up on the bottom shelf do not circulate and when you shift the shelves and move it up a shelf or two, it will circulate." Two others suggested that poor circulation figures for a particular title were the result of faulty classification or misleading subject headings, and would therefore order the cataloging department to make appropriate changes. According to these librarians, prudent judgment and professional knowledge about the value of a title should never be replaced by a blithe trust in statistical data. There may, in fact, be alternate explanations for low circulation figures, and it is the responsibility of the librarian to consider such possibilities.

For the librarians quoted above, weeding criteria that are based primarily on circulation counts reduce the ambit of their job to one of rote and technocratic procedure. For them, a constellation of human factors and professional insight should, instead, guide every weeding decision. Nonetheless, as Table 9 makes clear, these librarians are in the minority. Much more common is the view that, as one librarian bluntly stated, "I have no love affairs with any particular author or title." In many ways, the seemingly tedious and simple question of weeding brings into focus the emergent divide in the library profession between proponents of dispassionate managerial efficiency and those who approach librarianship from a more intellectual and humanistic-oriented viewpoint. For the former group, weeding is, for the most part, a means to offer a better product line; for the latter group, weeding is a balancing act that necessitates careful attention to a broad spectrum of interconnected issues, including classification, subject headings, reference work, tastes of individual readers, and the generalized knowledge and sensibility that comes from being able to recognize the value of Samuelson's Economics, color plates, and illustrated children's books.

As indicated in Table 9 (second and third questions), survey respondents were nearly unanimous in believing that weeding increases book usage $(91.8 \%)$ and patron satisfaction (86.1\%). This is not unexpected. It is interesting to note, however, the language of the arguments they use to make their point. Again and again respondents explained that overcrowded shelves repel patrons and discourage browsing. Patrons are accustomed to gleaming displays of new books at ever-increasingly sophisticated area bookstores, and they therefore have come to expect similar wares and displays at their local library. One survey respondent compared browsing at the library with "shopping in a large department storethere is so much merchandise, it is hard to see what there is and easy to get discouraged." Another librarian wrote that "crowded shelves and worn-out books are distasteful, especially to busy customers." In fact, the idea of busy lives was a recurring theme in these answers. Libraries are now frequented by "busy customers," who are accustomed to fast service in familiar and comfortable surroundings such as shopping malls. If the library does not provide a similar "shopping" experience, the "busy customer" will simply go elsewhere. As one librarian wrote, "I think public libraries are in direct competition with the national bookstore chains like Barnes and Noble. The public has come to expect shelves stocked with fresh, new clean books whether they are in their local library or in a bookstore." Another librarian noted that patrons are not so much interested in "early attic" collections. Or consider the views of the following librarian: "As a customer, I believe I would be more inclined to do business at a store where I don't have to wade through a lot of outdated, unappealing merchandise to 
find what I need and want. I would probably visit less often and certainly make fewer impulse purchases. I believe the same theory applies to library customers' use patterns." And, as many librarians pointed out, weeding also increases the level of trust between the library and its patrons. Outdated and obsolete materials may lead to embarrassment or serious mistakes, as in the case of "a teenager who uses an atlas of the USSR" rather than Russia, individuals who rely on a 1970 title about doing their own divorce, or travel guides more than three years old. Here, too, many librarians conceived the library in terms of a store. If a person received faulty goods at a store, would he or she frequent that store again in the future? The implication was: clearly not.

Weeding therefore functions as one way to increase the popularity and prestige of the public library. The result of weeding - a rapid turnover of stock - gives the impression of currency, vitality, and a sound understanding of the principles of the competitive marketplace, where patrons have steadily rising expectations and are constantly comparison shopping among other viable and trustworthy entertainment options. As one librarian explained, "space is tight, books have to earn their space." Competition among books-measured in terms of circulation data - is healthy because the stronger titles drive out the weaker titles, resulting in an overall better consumer experience. Just as a bookstore "remainders" titles that do not sell to make room for the constant arrival of new titles and to increase its sales and hence its profits - thus justifying its continued existence - so the public library must also do something to remove titles that do not circulate in order to retain and increase its budget allocations, which are often set in relation to the value and esteem in which the community holds the library, which in turn depends, to a large degree, on circulation figures. Also, just as a grocery store pulls discontinued and perishable items from its shelves to ensure that its customers do not suffer harm, the comments of some librarians suggested that libraries must treat information as a commodity that has an expiry date. In many respects, then, weeding not only allows the public library to make a claim to be a competitive force in the new entertainment marketplace, but it also allows the library, as four respondents put it, to provide "clean" and "fresh" material that will give patrons a "safe" feeling. As one librarian summarized, "[p] eople are not into the stuffed looking, dingy, dust smelling type of libraries anymore. They expect atmospheres more like coffeehouses or nice bookstores. People also like fresh smells and organization. I do try. . . to not let any shelf be less than half full and no more than half full. We burn scented candles and everyone loves the fresh smell and atmosphere."

The movement toward homogenization recalls George Ritzer's theory of McDonaldization, where services and procedures once subject to the fluctuations of human interaction undergo a rationalization process that emphasizes efficiency, predictability, calculability, and control [18]. Although named after the fast-food industry, Ritzer argues that the McDonaldization process has expanded to a variety of situations and venues, including credit cards, theme parks, and universities. Brian Quinn suggests that academic libraries too have succumbed, especially in the predictability and standardization of their collection development practices, "resulting in collection content varying less from one library or type of library to another" [19]. To judge by some of the comments presented here, weeding may function as a homogenizing agent in many public libraries, creating a situation where the product lines (books) offered show little variation from library to library. To be sure, 
librarians would likely be indignant at the suggestion that their local library has no differentiating features from the public library in the next town or city, but such differences are increasingly measured in the same way that McDonald's offers regional variations of its standardized menu in diverse countries.

\subsection{Weeding and new technologies}

There was a sharp division of opinion as to whether weeding is necessary "in order to make room for new technologies in the public library." As shown in Table 9 (fifth question), slightly more respondents replied in the affirmative (45.9\%) than in the negative $(39.8 \%)$ to this question, with a fairly large minority group hedging their answers with a "yes and no" reply $(11.9 \%)$. What do these figures mean? Some who replied in the affirmative suggested that, "although technology takes up a large chunk of space," there may actually be space savings once obsolete material is weeded, "especially in the case of reference materials where by the time that a book volume is published the information may be obsolete, while ... reference materials. . available in non-print formats are extremely current." Another librarian wrote that "weeding creates floor space for emerging technology - that is a good thing [because] patrons want information in all formats, not just print versions." Still another librarian indicated that "weeding is necessary to have space for just about anything new... . The space necessary for audio books, CDs, and videos as well as more public access computers has to come from the space that is used or could be used by books." In this regard, there were a number of librarians who offered stories about how they had had to eliminate "hard-copy back periodicals" or "3,000 hardback fiction books" to find sufficient place for computer workstations.

Those who responded in the negative to this question argued that weeding and the increase of information technologies in public libraries were independent phenomena. One librarian observed that "each medium has its place and weeding is done to make room for new books"; another was equally adamant that "we do not weed to make room for new technologies. We weed to make room for newer book titles." Others noted that "it really depends upon how much space and money you have." One respondent, calculating that a properly sized public computer workstation takes about as much space as 500 books, admitted that there are "real tradeoffs," but believed, overall, that books and new technologies supplement one another. The real issue, according to this individual, was "expanded space" in the form of larger library buildings. Indeed, the theme of larger buildings reappeared again and again. Libraries are not so much increasing weeding to make room for new technologies as they are increasing total square footage: "we are planning for building expansion"; "we are building bigger libraries"; "we have enlarged 4 libraries and are planning a $5^{\text {th }}$ to enlarge." Yet, as one librarian lamented, "what I am seeing here, and we are not unique, is a large percentage of our Internet stations being used for e-mail and chat-not what we envisioned when we started the service." Although increasing library size may resolve the vexed issue of "weeding for the sake of new technologies," what happens when those new technologies become mere e-mail and chat stations? In such cases, the mission of the public library has evolved - for better or worse. But it is an evolution that may come at the expense of weeded 
books that have been replaced by new technologies that may not be being used for their intended purposes.

\section{Conclusion}

As one of the final questions in this study (See Table 1, Question 16), librarians were asked to state their personal philosophy of weeding "not taking into account the procedures that your library actually follows in weeding." Of the 292 answers received to this question, 245 respondents $(83.9 \%)$ indicated that weeding is essential or vitally necessary for the ongoing good of the library, while only 22 respondents $(7.5 \%)$ wanted less weeding to occur. Their beliefs could be summed up as follows. Weeding is a fundamental activity that must be encouraged and embraced. Collections must be current, and must reflect what the community needs and will use. Certainly, weeding is personally difficult for many librarians because of their innate love of books, but if the public library is to be perceived as an appealing place, weeding is absolutely required. Weeding increases circulation, and increased circulation means that the library is "serving its community well." In addition, an up-to-date collection reflects a sense of responsibility, care, diligence, work, and a high level of knowledge among staff members. Accordingly, such a collection is more valuable to the community than one that gets used infrequently. Weeding also has a host of welcome byproducts. For example, staff members familiarize themselves with what does and does not circulate, thus greatly improving overall collection development choices. Weeding forces staff members to come face-to-face with obsolete information, which stimulates an awareness that reference sources must constantly be reviewed so as to provide patrons with correct information. The following response encapsulated the feelings of many:

\footnotetext{
My personal philosophy of weeding is that when a patron comes to the library for information, by virtue of an item residing on the library shelf, the patron will believe it is the best information available. Children are especially vulnerable, as they do not have the ability to discern what is good information. These younger patrons deserve their materials to be held to the same high standards as the adult materials. Having nothing on a subject is better than having materials that are misleading, inaccurate, and out-of-date.
}

Indeed, another librarian pointed out that weeding speaks to the very professionalism of librarians and the esteem in which libraries are held by the general public. "If librarians were held to the same professional standards as doctors and lawyers, we would need malpractice insurance to cover our liability in continuing to make available some of the misinformation on library shelves" (original emphasis). Weeding thus goes to the very core of the professional responsibilities of the librarian. Whether it is viewed as a "necessary evil" or as a pleasant task that demarcates the public library from the local archives or academic library, weeding, according to one respondent, should be something that is viewed as a professional task of the highest intellectual order. "If [weeding] is not done, there is just another reason not to have librarians . . . in this modern age of 'dumbing down' professions and replacing them with mindless clerks and voicemail...."

Many of the views of the public librarians surveyed here find echoes in prescriptive 
studies about the advantages of weeding. Segal, for instance, suggested that weeding has six advantages: saving space; saving time of patrons and staff; making the library more appealing; enhancing the reputation of the collection for reputability and currency; providing information about which items need to repaired or replaced; and providing feedback on the strengths and weaknesses of the collection [20]. There was an overwhelming belief that weeding increased book use $(91.8 \%)$ and the satisfaction of patrons $(86.1 \%)$ - so much so that $71.8 \%$ of public librarians had never saved a book that was designated for weeding (see Table 9). Moreover, $53.7 \%$ of surveyed librarians felt that weeding was a long-term timesaver, making both collection development and reference easier and faster (see Table 9). Many of the librarians subscribed to Sharon Baker's view that weeding decisions are, essentially, "product decisions" that must take into account varying life cycles [21].

At the same time, weeding is far from being simple, nor can it be reduced to an activity without broad implications. In fact, weeding raises a swirl of crucial issues that go to the very heart of library work. It gives rise to questions about the nature of what it means to be a library professional, as well as questions about the role and nature of the public library within the community and in the global competitive marketplace. It touches upon issues connected with new information technologies, and the juggling act that public libraries must perform to maintain both print collections and electronic resources. Weeding now has become an integral part of library and collection management procedures and protocols, contributing to the discursive formation of the public library as a venue that offers safe and clean "product lines" with various natural life cycles and expiry dates. Of course, the concept of weeding cannot be held responsible for commodification and homogeneity, but, in its current manifestation, weeding procedures that do not take into account factors other than circulation may have the effect of exacerbating commodification and homogeneity in the public library. When only the most popular books are found on library shelves, the intellectual choices available to patrons shrink and become standardized.

To be sure, the standardization process begins with selection. For example, in a study of how many "best general-interest books" of 1999 and "best academic books" (including books about the "democratic process") are held by 20 public libraries across the United States, John Budd and Cynthia Watt have shown that, while 29 of the 30 "best generalinterest books" are held at rates of more than $70 \%$ by the surveyed libraries, only 8 out of 19 "best academic books" are held at rates of more than $70 \%$ by the surveyed libraries [22]. These figures suggest that many public libraries initially have a uniform range of titles for patrons to choose from. But that range could shrink even further when the books in both "best" categories are weeded to reflect circulation data and to make way for new "best books." Public librarians will have to determine whether these standardization processes are positive and negative, and act accordingly.

Weeding may also contribute to making public library collections ephemeral. There is no denying that many public library patrons seek current materials, yet there are also users who desire older material, whether for pleasure or historical research. Although many respondents emphasized that it is the role of academic libraries and archives to preserve older materials, it is also true that such research venues are not always accessible to the public, whether because of distance or lack of institutional affiliation. As Matthew Simon observes, even though the public library is now perceived as a community and social center, a play space, 
a study hall, a museum, and a cultural center, it also remains a "window on the world" and a "warehouse of explosives ... whose shelves are ranked with the most furious combustibles in the world - the brains of men" [23]. Based on their views about weeding, many public librarians operate under the assumption that the only worthy "furious combustibles" are those of recent vintage. This may not necessarily be the case. If the library is to remain "a place of energy ... where one discovers a different but more valuable text while looking for a particular title" [24], it is important to understand fully how weeding does, or does not, contribute to making the library intellectually dynamic for all members of the public.

\section{Acknowledgments}

We would like to acknowledge Moya K. Mason, who provided research assistance for this project. We also acknowledge the students enrolled in the class FIS 2127 Collection Development and Evaluation at the University of Toronto during the 2000 Fall Term. Their names are listed in Appendix A.

\section{Appendix A}

\section{Names of students who sent out surveys for this study}

Esther Atkinson

Joanne Bainbridge

Robin Bergart

Maryann Breukelman

Keren Dali

Helen Flint

Denis Frias

Glenda Garbutt

Heather Glerum

Viveca Gretton

Susan Kun

Alexander Magno

Jo-Ann McQuillan

Loyd Mbabu

Patricia Richl

Mark Rose

Jessica Ross

Brian Vetruba

Carolyn Ziegler

\section{References}

[1] Roy, L. (1994). Weeding. In: A. Kent, \& H. Lancour (Eds), Encyclopedia of library and information science (p. 352-98). New York: Dekker (Volume 54, Supplement 17).

[2] Ibid., p. 355.

[3] Breisch, K. A. (1997). Henry Hobson Richardson and the small public library in America: a study in typology (p. 222-7). Cambridge, MA: The MIT Press. 
[4] Miller, J. W. (1984). Throwing out belles lettres with the bathwater. American Libraries, 15 (6), $384-5$.

[5] Slote, S. J. (1997). Weeding library collections: library weeding methods (4th ed), (p. 49-50). Englewood, CO: Libraries Unlimited.

[6] Segal, J. P. (1980). Evaluating and weeding collections in small and medium-sized public libraries: the CREW method (p. 3, 20). Chicago: American Library Association.

[7] Ibid., p. 10.

[8] Slote, S. J. Weeding library collections, p. 63.

[9] Carey, C. (1992). Survival weeding. In: B-C. Sellen, \& A. Curley (Eds), The collection building reader ( $\mathrm{p}$. 139-40). New York: Neal-Schuman Publishers.

[10] Jacob, M. (2001). Weeding the fiction collection: or should I dump Peyton Place? Reference \& User Services Quarterly, 40 (3), 234-9.

[11] McKee, P. (1981). Weeding the Forest Hill Branch of the Toronto Public Library by the Slote method: a test case. Library Research, 3, 283-301 (p. 298).

[12] Moore, C. (1982). Core collection development in a medium-sized public library. Library Resources \& Technical Services, 26 (1), 37-46 (p. 41).

[13] Roy, L. (1990). Weeding without tears: objective and subjective criteria used in identifying books to be weeded in public library collections. Collection Management, 12 (1/2), 83-93 (p. 90).

[14] Rouse, R. (1971). Within-library solutions to book space problems. Library Trends, 19 (3), 299-310.

[15] Futas, E., \& Tyron, J. S. (1990). Scheduled reference collection maintenance: the Rhode Island experience. Reference Librarian, 29, 69-76.

[16] Truett, C. (1990). Weeding and evaluating the reference collection: a study of policies and practices in academic and public libraries. Reference Librarian, 29, 53-68.

[17] Engeldinger, E. A. (1986). Weeding of academic library reference collections: a survey of current practice. $R Q, 25$ (3), 366-71.

[18] Ritzer, G. (1993). The McDonalidization of society: an investigation into the changing character of contemporary social life. Thousand Oaks, CA: Pine Forge.

[19] Quinn, B. (2001). The McDonaldization of academic libraries? College \& Research Libraries, 61 (3), 248-61 (p. 252).

[20] Segal, Evaluating and weeding collections, p. 3.

[21] Baker, S. L. (1993). The responsive public library collection: how to develop and market it (p. 66-7). Englewood, CO: Libraries Unlimited.

[22] Budd, J. M., \& Watt, C. (2002). "Do you have any books on . . ": an examination of public library holdings. Public Libraries, 41 (2), 107-12.

[23] Simon, M. (2002). Will the public library survive the Internet? What patrons value in public libraries. Public Libraries, 41 (2), 104-6. Simon quotes Christopher Morley's The Haunted Bookshop (1919).

[24] Ibid., p. 106. 